\title{
Biochemical composition of black currant berries (Ribes Nigrum L.) for development of new cultivars in Bashkortostan
}

\author{
Radmil Nigmatzyanov ${ }^{1 *}$, Vladimir Sorokopudov², and Nadezhda Nazaryuk ${ }^{3}$ \\ ${ }^{1}$ Kushnarenkovsky breeding center of fruit and berry crops and grape of the Bashkir Research Institute of Agriculture, UFIC RAS, \\ Republic of Bashkortostan, Ufa, Russia \\ ${ }^{2}$ Russian State Agrarian University - K.A. Timiryazev MAA, Moscow, Russia \\ ${ }^{3}$ FSBSI FANTSA Department "Scientific Research Institute of Horticulture of Siberia named after M.A. Lisavenko», Barnaul, Russia
}

\begin{abstract}
The paper presents the results of researches of the biochemical composition of black currant berries (Ribes nigrum L.), cultivated in the Republic of Bashkortostan. The objects of the research were cultivars breeding of the Bashkir Research Institute of Agriculture: Valovaya (control), Karaidel, Chishma, Kushnarenkovskaya, Belskaya and Estafeta. Observations have been carried out for 12 years (2006-2017). Differences in the accumulation of components of the biochemical composition are shown in dependence of the varietal peculiarities of the crop. Cultivars that can be used in breeding as sources of individual economically valuable sources are selected.
\end{abstract}

\section{Introduction}

Blackcurrant (Ribes nigrum L.) is the leading berry crop in the Republic of Bashkortostan [1]. This is due to the high yield, therapeutic and dietary properties of berries and their suitability for all types of technical processing $[1,2]$.

Cultivars of black currant ( $R$. nigrum L.) from the Bashkir RIA - Valovaya, Chishma, Karaidel and Kushnarenkovskaya - are complex three-genome hybrids, originating from European and Siberian subspecies, as well as from the species Dikusha. Having a high adaptive potential, these cultivars were selected as promising donors for breeding of black currant. One of the priority tasks of modern breeding is the cultivation of highly productive cultivars $[3,4]$. The identification of nutrients valuable in terms of the content of nutrients in berries of cultivated varieties is a necessary study for breeding of black currant.

Researches of the biochemical composition of black currant berries ( $R$. nigrum L.) in various cultivars were carried out in many regions of Russia and abroad [5-11]. It was noted that the level of nutrients in the berries of black currant $(R$. nigrum L.) is a key feature in the breeding of this crop.

\section{Experimental}

The researches were carried out at the Kushnarenkovsky breeding center for fruit and berry crops and grape in 2006-2017, in accordance with the program and method of the variety study of fruit, berry and walnut crops [5]. Biochemical analysis of black currant berries was carried out in the analytical laboratory of the Bashkir Research Institute of Agriculture, according to the methods [2]. The objects of the research were black currant cultivars from the Bashkir RIA: Valovaya, Chishma, Karaidel, Kushnarenkovskaya, Belskaya, Estafeta $[1,2]$. The control was a cultivar of early ripening - Valovaya.

\section{Results and discussion}

The biochemical composition of the berries determines the taste and dietary properties of black currant. The results of long-term studies of the biochemical composition of black currant berries ( $R$. nigrum L.) in the Republic of Bashkortostan are presented in Table 1.

The biochemical composition of the berries of black currant (R. nigrum L.) is an important indicator, defining the value of the cultivar [12-14].

Among the traditional berry crops, black currant occupies the leading place in the accumulation of soluble dry substances [15-16]. In the berries of black currant of Bashkir breeding, the content of soluble solids (SDS) was $18.7 \pm 0.6 \%$. The SDS content in berries varied from 17.3 $\pm 0.4 \%$ (Belskaya) to $19.8 \pm 0.7 \%$ (Chishma). The cultivars Karaidel $-19.3 \pm 1.4 \%$ and Chishma $-19.8 \pm$ $0.7 \%$ had the higher SDS content, compared with the control cultivar Valovaya $-18.9 \pm 1.0 \%$.

The maximum accumulation of SDS was observed in cultivars: Kushnarenkovskaya - 19.5\%, Belskaya $21.6 \%$, Estafeta - 21.7\%, Chishma - 22.2\%, Valovaya $23.6 \%$, Karaidel $-31.9 \%$.

The minimum SDS accumulation was observed in the cultivars: Valovaya - $13.4 \%$, Kushnarenkovskaya -

\footnotetext{
*Corresponding author: radmil.nigmatzyanov@yandex.ru
} 
14.0\%, Karaidel - 14.1-14.4\%, Chishma - 14.9\%, Estafeta - 15.9\%, Belskaya - 16, 4\%.

According to the results of biochemical analysis of black currant berries, the stability of SDS accumulation of black currant berries was noted. The coefficient of variation averaged $4.3 \%$. The variability range is from $2.4 \%$ (Belskaya) to $7.3 \%$ (Karaidel).

In the berries of black currant sugars are represented by glucose, fructose and sucrose.

The total sugar content in the berries of black currant, in different years of researches, was at the level of $8.9 \pm$ $0.4 \%$. This index ranged from $8.3 \pm 0.3 \%$ (Kushnarenkovskaya) to $9.6 \pm 0.6 \%$ (Estafeta). The cultivars Chishma $-9.2 \pm 0.4 \%$, Karaidel $-9.2 \pm 0.8 \%$ and Estafeta- $9.6 \pm 0.6 \%$ had the higher total sugar content, compared with the control cultivar Valovaya $8.9 \pm 0.8 \%$.

In the cultivars of black currant, we studied, the maximum and minimum indices of sugar content in berries were noted:

-maximum indices: Kushnarenkovskaya - 9.8\%, Chishma $-11.4 \%$, Belskaya $11.9 \%$, Valovaya - 12.9\%, Karaidel $13.1 \%$, Estafeta - 13.3\%;

-minimum indices: Valovaya - 3.9\%, Karaidel - 5.9\%, Kushnarenkovskaya - 6.5\%, Estafeta $-6.7 \%$, Chishma 7.3, Belskaya $-7.9 \%$.

By the level of accumulation of sugars, cultivars of Bashkir breeding were distinguished by high homeostaticity. The average values [11] of the coefficient of variation, for all cultivars, amounted to $6.0 \%$ with a range of variability from $3.8 \%$ (Kushnarenkovskaya) to $8.7 \%$ (Valovaya).

Sugars, in combination with organic acids, form the taste of berries. Black currant berries are highly acidic compared with other species of currants [6]. Black currant berries contain: citric, tartaric, succinic, salicylic, malic, phosphoric acids.

The berries of Bashkir black currant breeding are characterized by a moderate content of titrated acid. The total titrated acid content in berries varied from $1.9 \pm 0.3 \%$ (Valovaya) to $2.3 \pm 0.3 \%$ (Belskaya). The average content

Table 1. The biochemical composition of black currant berries on average for the period 2006-2017.

\begin{tabular}{|c|c|c|c|c|}
\hline Cultivar name & $\begin{array}{c}\text { Soluble dry substance, } \\
\text { (SDS), \% } \\
\mathbf{x} \pm \mathbf{m} \\
\text { min - max }\end{array}$ & $\begin{array}{c}\text { Total sugar } x \pm m \\
\text { min - max }\end{array}$ & $\begin{array}{c}\text { Titrated acid, \% } \\
\begin{array}{c}\mathbf{x} \pm \mathbf{m} \\
\min -\max \end{array}\end{array}$ & $\begin{array}{c}\text { Ascorbic acid mg/100g } \\
x \pm m \\
\text { min - max }\end{array}$ \\
\hline Valovaya & $\frac{18,9 \pm 1,0}{13,4-23,6}$ & $\frac{8,9 \pm 0,8}{3,9-12,9}$ & $\frac{1,9 \pm 0,3}{0,8-3,9}$ & $\frac{157,0 \pm 7,7}{107,1-197,0}$ \\
\hline Karaidel & $\frac{19,3 \pm 1,4}{14,1-31,9}$ & $\frac{9,2 \pm 0,8}{5,9-13,1}$ & $\frac{2,1 \pm 0,3}{0,7-3,6}$ & $\frac{161,7 \pm 8,5}{119,0-193,3}$ \\
\hline Kushnarenkovskaya & $\frac{18,3 \pm 0,6}{14,0-19,5}$ & $\frac{8,3 \pm 0,3}{6,5-9,8}$ & $\frac{2,0 \pm 0,2}{0,9-3,4}$ & $\frac{138,0 \pm 5,0}{107,3-163,5}$ \\
\hline Chishma & $\frac{19,8 \pm 0,7}{14,9-22,2}$ & $\frac{9,2 \pm 0,4}{7,3-11,4}$ & $\frac{2,0 \pm 0,2}{0,7-3,9}$ & $\frac{191,7 \pm 15,5}{98,7-236,0}$ \\
\hline Belskaya & $\frac{17,3 \pm 0,4}{16,4-21,6}$ & $\frac{8,7 \pm 0,4}{7,9-11,9}$ & $\frac{2,3 \pm 0,3}{0,8-4,1}$ & $\frac{162,7 \pm 6,5}{98,2-190,1}$ \\
\hline Estafeta & $\frac{18,3 \pm 0,7}{15,9-21,7}$ & $\frac{9,6 \pm 0,6}{6,7-13,3}$ & $\frac{2,1 \pm 0,3}{0,9-3,7}$ & $\frac{161,7 \pm 7,0}{100,0-197,9}$ \\
\hline X cp. & $18,7 \pm 0,6$ & $8,9 \pm 0,4$ & $2,1 \pm 0,2$ & $162,1 \pm 6,5$ \\
\hline Min-max & $14,8-23,4$ & $6,4-12,1$ & $0,8-3,9$ & $105,1-196,3$ \\
\hline $\mathrm{V}, \%$ & 4,3 & 6,0 & 12,9 & 4,0 \\
\hline
\end{tabular}

of titrated acid in berries was at the level of $2.1 \pm 0.2 \%$. In the cultivars studied by us, in different years of observation, the minimum and maximum content of titrated acid in berries was noted: Karaidel 0.7-3.6\%, Chishma 0.7-3.9\%, Valovaya 0.8-3.9\%, Belskaya 0.8$4.1 \%$, Kushnarenkovskaya $0.9-3.4 \%$, Estafeta $0.9-3.7 \%$. The coefficient of variation was, on average, $12.9 \%$, which indicates the average stability of the character. For black currant cultivars, the coefficient of variation was: Kushnarenkovskaya - 9.3\%, Chishma - 11.7\%, Belskaya $-12.5 \%$, Karaidel $-13.5 \%$. Estafeta - 14.1\%. Significant variability of the character was observed in the control cultivar Valovaya $-16.2 \%$.

One of the main indices that determine the value of cultivars in horticulture is the content of ascorbic acid (AA) in fruits and berries [10]. The AA content in the berries of black currant varies widely and is determined mainly by the genetic characteristics of the cultivar, the level of applied agricultural technology and environmental conditions [4].

According to long-term researches, it was found that the cultivars of Bashkir breeding, is $162.1 \pm 6.5 \mathrm{mg} / 100 \mathrm{~g}$. The AA content in berries ranged from $138.0 \pm 5.0 \mathrm{mg} /$ $100 \mathrm{~g}$ (Kushnarenkovskaya) to $191.7 \pm 15.5 \mathrm{mg} / 100 \mathrm{~g}$ (Chishma). Cultivars Estafeta $-161.7 \pm 7.0 \mathrm{mg} / 100 \mathrm{~g}$, Karaidel $-161.7 \pm 8.5 \mathrm{mg} / 100 \mathrm{~g}$, Belskaya $-162.7 \pm 6.5$ $\mathrm{mg} / 100 \mathrm{~g}$ and Chishma - $191.7 \pm 15.5 \mathrm{mg} / 100 \mathrm{~g}$ were characterized by an increased AA content, compared with the control cultivar Valovaya $-157.0 \pm 7.7 \mathrm{mg} / 100 \mathrm{~g}$. In cultivars of Bashkir black currant breeding, in different years of observation, the minimum and maximum AA content in berries was noted: Belskaya - 98.2 - $190.1 \mathrm{mg} /$ 100g, Chishma - 98.9 - $236.0 \mathrm{mg} / 100 \mathrm{~g}$, Estafeta - 100, 0 - $197.9 \mathrm{mg} \mathrm{mg} \mathrm{/} 100 \mathrm{~g}$, Valovaya- $107.1-197.0 \mathrm{mg} /$ 100 g, Kushnarenkovskaya - 107.3 mg - 163.5 / 100 g, Karaidel - 119.0 - $193.3 \mathrm{mg} / 100 \mathrm{~g}$.

The coefficient of variation of AA, in different years, was insignificant and averaged $4.0 \%$ with a variability range from $3.6 \%$ (Kushnarenkovskaya) to $8.1 \%$ (Chishma). content of ascorbic acid (AA) in berries of black currant 


\section{Conclusion}

As a result of long-term researches of black currant berries, differences in the accumulation of the main components of the biochemical composition were revealed.

Cultivars of black currant (Ribes nigrum L.) of Bashkir breeding cultivated in the Republic of Bashkortostan contain on average: $18.7 \pm 0.6 \%$ soluble solids, $8.9 \pm 0.4 \%$ sugars, $2.1 \pm 0,2 \%$ titrated acids and $162.1 \pm 6.5 \mathrm{mg} / 100 \mathrm{~g}$ ascorbic acid.

The following cultivars, which can be used in breeding as a source of separate economically-valuable characters are selected:

- high solids content: Valovaya - $18.9 \pm 1.0 \%$, Karaidel $-19.3 \pm 1.4 \%$ and Chishma $-19.8 \pm 0.7 \%$;

- high accumulation of sugars: Karaidel $-9.2 \pm 0.8 \%$ and Estafeta $-9.6 \pm 0.6 \%$.

- low content of titrated acid: Valovaya $-1.9 \pm 0.3 \%$, Kushnarenkovskaya $-2.0 \pm 0.2 \%$, Chishma $-2.0 \pm 0.2 \%$;

- high content of ascorbic acid: Belskaya $-162.7 \pm 6.5$ $\mathrm{mg} / 100 \mathrm{~g}$ and Chishma $-191.7 \pm 15.5 \mathrm{mg} / 100 \mathrm{~g}$;

- stability of the accumulation of components of the biochemical composition - Kushnarenkovskaya and Belskaya.

The cultivars of Bashkir black currant breeding Valovaya, Chishma, Karaidel, Kushnarenkovskaya, Belskaya, Estafeta meet modern market requirements for the quality of berries, their nutritional value and medicinal properties.

\section{References}

1. R.A. Nigmatzyanov, L.A. Golovina, Collection of scientific articles. - prakt. conferences. 77 (2019)

2. M.G. Abdeeva, R.A. Nigmatzyanov, Sat. articles scientific. conferences. 59 (2014)

3. S.D. Knyazev, A.N. Zarubin, A.U. Andrianov, Gardening and viticulture. 4, 26 (2012)
4. T.V. Zhidekhina, O.S. Rodyukova, S.A. Magomedova, Gardening and viticulture. 5, 15 (2007)

5. A.V. Zaritsky, Far Eastern agrarian Bulletin. 1, 25 (2018)

6. E.N. Dzhigadlo, E.A. Dolmatov, V.V. Zhdanov, S.D. Knyazev, N.G. Krasova, T.P.Ogoltsova, E.N. Sedov, G.A. Sedysheva, Program and method of variety study of fruit, berry and nut crops (1999)

7. R.R. Kildiyarova, E.A. Ivanova, F.K. Juraeva, Collection of scientific papers for the 75th anniversary of the Institute. 102 (2011)

8. T.G. Prichko, V.V. Yakovenko, M.G. Germanova, Fruit growing and viticulture in the South of Russia, 45, 105 (2017)

9. F.F. Sazonov, Collection of articles international. nauch-prakt. Conferences, 271 (2017)

10. V.S. Salykova, L.S. Sankin, Modern gardening. 1, 13 (2010)

11. O.A. Tikhonova, T.V. Shelenga, S.A. Streltsina, Selection and variety distribution of garden crops: Collection of articles of the international journal. nauch-prakt. conferences. 203 (2015)

12. S.M. Paunović, M.R. Nikolić, "XXI savetovanje o biotehnologiji” Zbornik radova. 21, 233 (2016)

13. M. Vagiri, Balsgård Swedish University of Agricultural Sciences. 2 (2012)

14. T.L.Woznicki, O.M. Heide, A.Sønsteby, A.B. Wold, S.F. Remberg, Acta Agriculturae Scandinavica, Section B - Soil \& Plant Science. 65, 702 (2015)

15. D. Bonarska-Kujawa, S. Cyboran, R. Gybka, J. OszmiaNski, H. Kleszczynska, Hindawi Publishing Corporation BioMed Research International (2014)

16. A. Kikas, K. Kahu., L. Arus, H. Kaldmäe, R. Rätsep, A.V. Libek, Proceedings of the Latvian academy of sciences, Section B. 71, 190 (2017) 